\title{
A study on systematic theology
}

\begin{tabular}{|c|c|}
\hline $\begin{array}{l}\text { Book Title: } \\
\text { Faith in Christ } \\
\text { Invitation to S } \\
\text { Theology. Vol } \\
\text { the Presence } \\
\text { II: Involved in }\end{array}$ & $\begin{array}{l}\text { Today. } \\
\text { /stematic } \\
\text { me 1: Life in } \\
\text { f God. Volume } \\
\text { God's Project }\end{array}$ \\
\hline Book Cover: & \\
\hline Klaus Nürnberge & \\
\hline Faith in $C$ & irist \\
\hline $\begin{array}{l}\text { Invitation to } \\
\text { Systematic } \\
\text { Theology }\end{array}$ & $+=$ \\
\hline Involved in God & $\begin{array}{l}\text { lume II } \\
\text { project }\end{array}$ \\
\hline $\begin{array}{l}\text { Author: } \\
\text { Klaus Nürnbe }\end{array}$ & \\
\hline $\begin{array}{l}\text { ISBN: } \\
978-1514463\end{array}$ & \\
\hline $\begin{array}{l}\text { Publisher: } \\
\text { Pietermaritzb } \\
\text { 2016, R553.9 } \\
\text { *Book price a }\end{array}$ & $\begin{array}{l}\text { Irg, Cluster, } \\
\text { time of review }\end{array}$ \\
\hline $\begin{array}{l}\text { Review Title: } \\
\text { A study on sys } \\
\text { theology }\end{array}$ & tematic \\
\hline $\begin{array}{l}\text { Reviewer: } \\
\text { J. H. van Wyk }\end{array}$ & \\
\hline $\begin{array}{l}\text { Affiliation: } \\
{ }^{1} \text { Unit for Rene } \\
\text { Theology, Nor } \\
\text { University, Po } \\
\text { Campus, Sout }\end{array}$ & $\begin{array}{l}\text { wal of } \\
\text { h-West } \\
\text { chefstroom } \\
\text { Africa }\end{array}$ \\
\hline $\begin{array}{l}\text { How to cite th } \\
\text { Van Wyk, J.H. } \\
\text { on systematic } \\
\text { die Skriflig } 52 \\
\text { https://doi.or } \\
\text { v52i1.2329 }\end{array}$ & $\begin{array}{l}\text { is book review: } \\
2018, \text { 'A study } \\
\text { theology', In } \\
\text { 1), a2329. } \\
\text { /10.4102/ids. }\end{array}$ \\
\hline $\begin{array}{l}\text { Copyright: } \\
\text { (c) 2018. The } \\
\text { Licensee: AOS } \\
\text { is licensed un } \\
\text { Creative Com } \\
\text { Attribution Lic }\end{array}$ & $\begin{array}{l}\text { uthors. } \\
\text { S. This work } \\
\text { ler the } \\
\text { nons } \\
\text { ense. }\end{array}$ \\
\hline Read online: & \\
\hline 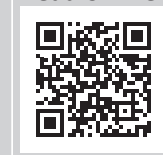 & $\begin{array}{l}\text { Scan this QR } \\
\text { code with your } \\
\text { smart phone or } \\
\text { mobile device } \\
\text { to read online. }\end{array}$ \\
\hline
\end{tabular}

In 1975 Klaus Nürnberger was the first South African to publish a full study on systematic theology, called Sistematiese Teologie. After 40 years of study, lecturing and writing he now published his seasoned study on the same topic, this time in two volumes which cover more than 1000 pages. It is an intriguing exercise to see how the views of the author developed and changed through the decades of theological reflection. On the last pages of his book the author did us a favour by setting out and explaining the way he travelled as theologian and how he finally reached his matured considerations. He consistently followed the experiential-realist approach, continuing on the same line as critical exponents of the Lutheran tradition in Central Europe during the twentieth century tradition. He also followed an unambiguous historical-critical reading of the Bible and related and linked the message of the Bible with other disciplines such as natural sciences.

The author also assists us by giving a summary of his message in a nutshell at the beginning of his book, which I will now summarise to clarify his way of thinking.

He starts by saying that theology is the quest of believers for an understanding of what they believe. This means that faith comes first and then follows theology. Religious faith is the intuition that reality is derived from a transcendent Source and headed towards a transcendent Destiny, while theology seeks to clarify this intuition. Then follows what may be called the essence of the whole argument: 'Christian faith responds to the "Word of God", that is, the message of God's creative power, God's benevolent intentionality and God's comprehensive vision for the world as manifest in Christ'. As far as the biblical material is concerned, the author focuses on Genesis and Deuteronomy, Paul and his school, the Synoptic Gospels and the writings of John.

The Word of God is not described as a static entity but as a Word that emerged and evolved in human history in the form of a living tradition. During biblical times it functioned as God's redemptive response to the specific human predicament and worldviews, culminating in the Christevent. The Word of God is proclaimed by each successive generation of believers on the basis of the biblical tradition. Whenever we accept this message in faith it manifests its power by calling us into God's presence, accepting us into God's fellowship and transforming us in(to) God's vision for the world.

In the face of all contradictory indications, we believe this reality to be the ever new outcome of God's creative power and benevolent intentionality. Faith is therefore always a tenacious struggle to remain open for the reassurance of God's benevolence against the vagaries of experienced reality. This faith is always challenged in a never-ending process. After three millennia one has to figure out which is the best way of interpreting the ever-changing message of God.

The author views it as the task of theology to provide a reasonably comprehensive and consistent overview of the Christian faith as a whole.

The contents of the two volumes deal with the following material:

Volume I deals with the question what life in the presence of God might entail. The focus here is on the Word of God as the medium used by God to make himself present and known in our lives (Part I). This is followed by Part II which deals with our being embedded in the Christian community.

Chapter 1 tries to answer the following question: We have the Bible, why then is theology important?

Part I deals with life in the presence of God, with the living Word of God, with the following divisions: encounter with God in his Word (Ch. 2); facets of the Word of God (law and grace) 
(Ch. 3); the origins of the Word of God (Scriptures and traditions) (Ch. 4); the transmission of God's Word (hermeneutics) (Ch. 5); the dynamics of God's Word (mission) (Ch. 6).

The heading of Part II reads: 'At home in God's fellowship', with the following divisions: the embodied Word of God (the community of believers) (Ch. 7); the embedded Word of God (church and world) (Ch. 8); the herald of the Word of God (the ordained ministry) (Ch. 9); the celebration of God's Word (worship and the sacraments) (Ch. 10); keeping God's Word on track (orthodoxy and heresy) (Ch. 11).

Volume II goes back a step and asks who this God is. It deals with the topic. 'Involved in God's project' - 'reflections on God'. The word God serves as a name for the ultimate Source and Destiny of reality.

Part III investigates the subject, 'the transcendence of God', with the following subheadings: Who is this God? (the concept of God) (Ch. 12) and finding an appropriate approach (theological accountability) (Ch.13).

Part IV reflects on 'the creative power of God', dealing with 'God, the transcendent Source of reality' (the concept of creation) (Ch. 14) and 'the human being as a creature of God' (anthropology) (Ch. 15).

Part V deals with a key feature, namely the benevolent intentionality of God' where the following subdivisions are made: 'the disclosure of God's intentionality' (Jesus of Nazareth) (Ch.16); 'the elevated Christ' (the resurrection and ascension of Christ) (Ch. 17); 'the presence of Christ' (the Holy Spirit (Ch. 18); 'God against God' (the Trinity) (Ch. 19).

Part VI considers 'the comprehensive vision of God' as follows: 'a world in need of redemption' (where are we in human history?) (Ch. 20); 'God and the quest for human wellbeing' (Ch. 21); 'God and the quest for human authenticity' (sin and reconciliation, including an appendix which deals with traditional approaches to soteriology) (Ch. 22).

Part VII, the last part, investigates the theme, 'God beyond space and time', dealing with the following: 'a new kind of creation?' (eschatology) (Ch. 23); our future beyond death' (eternal life, with an appendix: key stages in the evolution of eschatology) (Ch. 24). The last chapter (Ch. 25) consists of a biography of the author, followed by a list of publications.

This massive study of Nürnberger must be seen as his magnum opus, a book of high academic standard which challenges classic orthodoxy in many ways. The author is well-informed, 'broadminded', a man of wide reading, intelligent argumentation and always thought-provoking to repeat my words on the back cover. It is impossible to write such a book at the beginning of one's theological investigations, it can only be written after a long and sometimes exhausting theological career.

It is impossible to evaluate all aspects which are discussed in the book and therefore I would like to consider only a few facets for further consideration.

My first question would be about the view on Scripture. The author opts for a (sometimes very) critical approach to the Bible. I fully agree with him that a fundamentalist approach obscures the biblical message, but so does a modernist interpretation. A transformist-contextual approach, which considers the context of the first readers, the context of the text in the Bible and the context of the modern readers, supplies us with reasonable tools to interpret the gospel message.

The author constantly relates the Word of God and natural sciences (evolution), or to put it in more orthodox terminology: the word of God in Scripture and the word of God in nature. This is a very important and necessary exercise because the one God could not contradict himself in his twofold utterance. But it is also a very difficult and complicated exercise because there is always the temptation to give priority to the scientific interpretation because science can easily be verified or falsified. But when science speaks the last and final word, the message of the gospel is obscured. It is impossible to deduct from natural science alone the gospel message of salvation through Jesus Christ.

I here refer specifically to Christology and eschatology. The author argues that although 'Christian faith is a living relationship with Jesus Christ, our "personal Saviour"' (II:243), the idea of a bodily resurrection of Christ is untenable. 'The risen Christ is the prototype of a sacrificial life. He lived and died on our behalf, and we are allowed to participate in his life and death on behalf of others' (II:230).

'The cross of Christ is the core of the New Testament message' (II:508). 'God's suffering, self-giving love, as manifest in the Christ-event, is the core of the Christian faith' (II:508). There is no reference to the resurrection of Christ in this respect. Science excludes the message of a real resurrection of Christ - and I italicised the word science in the following quotations to clarify the emphasis on science in what follows.

Eternal life, apocalyptic eschatology and expectations are futile. Realistic eschatology is not likely to materialise (II:481, 492). 'Science has provided us with a deeper insight into reality than could have been available to the authors of the Bible' (II:481). All we can do, is to strive relentlessly in the direction of comprehensive optimal well-being (II:478). Both propositions (Paul's and Plato's on the resurrection) 'are also untenable in terms of scientific insight' (II:493).

It is important to realise that the assumption of a new life after death, if taken literally, is just as improbable as the assumption of a new creation without entropy after the existing world has reached it's catastrophical end (II:485). 
It is clear therefore, that the concept of 'eternal' life in the New Testament does not refer to Platonic timelessness, or to endless continuation of biological life, but to a life in unobstructed fellowship with God lived here and now ... resurrection and eternal life were essentially about authenticity rather than longevity (II:497).

There will come a time when we will cease to exist. But the consequences of our lives will continue at least up to the end of life on planet earth (II:506)

Modern scientific insight excludes a literal quasi-biological interpretation [of resurrection from the dead] (II:511).

Orthodox eschatology must be rejected as 'heretical' (II:511).

The questions which come to the fore when we 'spiritualise' the resurrection of Jesus Christ are the following:

- There is a consensus amongst many prolific New Testament scholars that the first confession of the early Christians was: 'The Lord is risen indeed!' (Lk 24:34).

- The truth of this fundamental confession is verified by the fact that in the book of Acts there is no reference in the speeches and sermons to the crucifixion of Christ as a saving and life-giving fact in the first 19 chapters. The emphasis here is on the resurrection of Christ as the culmination of God's redemptive action to mankind. Only from Chapter 20 onwards does the cross of Christ appear in the same manner.

- This truth is illustrated by the fact that Paul could summarise the gospel with these words: 'If you confess that Jesus is Lord and believe that God raised him from death, you will be saved' (Rm 10:9). Or: 'Remember Jesus Christ, raised from the dead, descended from David. This is my gospel ...' (2 Tm 2:8).

- The oldest book in the New Testament refers explicitly to the resurrection (1 Th 1:9-10; 4:13-18).

- It seems that already in the New Testament a purely 'spiritual' (and gnostic) interpretation of the resurrection is mentioned but rejected (see 2 Tm 2:17; Hymenaeus and Philetus).

- All four Gospels, including the one by a medical doctor (Luke), explicitly refer to the resurrection, although with variations. Even Paul tells us that he met the risen Christ.

- All four Gospel writers, even Paul, mention the appearance of the risen Christ to living persons.

- The message of the risen Christ was preached in a Hellenistic context in which the resurrection of a person was severely questioned. The message of Paul brought him in direct conflict with the idealism of Plato and the materialism of Epicurus and Stoa (Ac 17).

- Paul reflects on the raising of the Lord Jesus as a demonstration of the power of the God of creation (Rm 8:11; 1 Cor 5:14).

- In the whole of the New Testament the risen Christ is described as the living Lord and not as a dead person to whom believers must thankfully relate. Would the early Christians be willing to die for a dead person who had given them only a wonderful example of a good life? To what must the fast growth of Christianity during the early centuries be attributed?

- If Jesus was not resurrected, what meaningful interpretation should be given to the empty tomb?

- The transition of the Sabbath as day of worship to the Sunday (first day) as 'Day of the Lord' which took place in the Early Church, can be fully attributed to the fact that Christ was raised from the dead on the Sunday morning.

- Lastly, and not the least, how can Western theologians communicate in a sensible way with Eastern Orthodox theologians, who did not experience the Aufklärung with its rationalism and for whom the resurrection of Christ is an essential part of the gospel message?

Although the author claims that he rejects the views of Bultmann, it is an open question whether Bultmann did not influence many of his conclusions.

To clarify any misunderstanding, I want to add that we should not understand the resurrection of Christ in the same way as the resurrection of Lazarus, who died again. Christ went through death and appeared after his resurrection in a transformed way as victor and living Lord.

I come to the following conclusion: Although I made some critical comments, it would be wrong to conclude from this that this is not a very important study undertaken by a prolific and bright scholar who asks for sensible reading, a book which is going to be very influential. The author clearly shows that it is no longer possible to do theology in isolation and that the study of 'science and theology' will become more and more important.

I strongly recommend the (critical) reading of this book by Nürnberger.

\section{Postscript}

In a personal e-mail conversation with the author, he asked me to include the following sentences to clarify his view:

1. For KN science does not have the last word, because (a) in terms of the current worldview it is always provisional and (b) in terms of the redemptive intentionality of God as it manifested itself in Christ it has nothing to say whatsoever.

2. Christ is alive for KN. He has written a whole chapter on the elevation of Christ. He used the word 'elevation' of Christ rather than 'resurrection' because he thinks it reflects the reality of Christ for us today better. It is the bodily crucified Jesus who has become the 'Lord' for us and who manifests himself in our bodies.

3. My approach of experimental realism is based on 1 Cor 9:19-23 - becoming all things to all people - thus driven by a missionary agenda. 